\title{
Seasonal variation in the biochemical composition of the chaetognath Parasagitta elegans from the hyperbenthic zone of Conception Bay, Newfoundland
}

\author{
Nami Choe*, Don Deibel, Raymond J. Thompson, Sing H. Lee, Vivian K. Bushell \\ Ocean Science Centre, Memorial University of Newfoundland, St. John's, Newfoundland A1C 5S7, Canada
}

\begin{abstract}
The biochemical composition of the chaetognath Parasagitta elegans from the hyperbenthic zone of Conception Bay, Newfoundland, was determined from April 1997 to June 1998. Lipid and carbohydrate levels (\% dry weight) were relatively high in the spring and summer and low in the fall and winter. Conversely, the relative protein level was low in the spring and summer and high in the fall and winter. Carbon level was generally high in the spring and summer of 1997 but low from fall to the following spring, whereas inorganic ash level showed the opposite seasonal trend. Lipid and carbohydrate levels and the $\mathrm{C} / \mathrm{N}$ ratio were positively correlated with chaetognath maturity stage, while protein levels were negatively correlated with chaetognath maturity. These results indicate that $P$. elegans were lipid- and carbohydrate-rich while maturing during spring and summer, and that immature individuals were protein-rich while achieving somatic growth during fall and winter. This increase in the levels of lipid and carbohydrate occurred when mature copepods increased in the spring and summer rather than when total abundance of copepods increased in the fall. Thus, it appears that food quality rather than quantity affects the biochemical levels and reproductive cycle of $P$. elegans. In addition, the maximum abundance of adult copepods occurred $3 \mathrm{wk}$ after the peak of the spring bloom, and the maximum relative abundance of mature $P$. elegans occurred $3 \mathrm{wk}$ later. This suggests that there is tight coupling of energy transfer from primary producers to carnivorous hyperbenthic chaetognaths following the spring phytoplankton bloom in Newfoundland coastal waters. Therefore, seasonal variation in the biochemical composition of $P$. elegans in the hyperbenthic zone of Conception Bay is closely related to its reproductive cycle and to food quality. Furthermore, it is clear that the chaetognath reproductive cycle is synchronized with the massive energy input from the annual spring phytoplankton bloom.
\end{abstract}

KEY WORDS: Parasagitta elegans - Chaetognath - Biochemical composition · Seasonal variation · Reproductive cycle $\cdot$ Trophodynamics

\section{INTRODUCTION}

In temperate and polar waters, seasonal variation in the biochemical composition of zooplankton is related to food availability and the reproductive cycle. Copepods, euphausiids, amphipods, ctenophores and medusae may experience an increase in lipid levels in response to the spring phytoplankton bloom (Sargent et al. 1978, Percy 1979, Falk-Petersen 1981, Percy \& Fife 1981, Alonzo et al. 2000, Pasternak et al. 2001). Many crustaceans such as copepods, euphausiids and benthic amphipods store lipid in the form of wax esters and triacylglycerols to be utilized for subsequent reproductive maturation prior to the next bloom (Littlepage 1964, Lehtonen 1996, Falk-Petersen 1981, Hopkins et al. 1984, Kosobokova 1999, Niehoff et al. 1999, 
Alonzo et al. 2000, Pasternak et al. 2001). This strategy can be beneficial when the release of juveniles is matched with abundant food. In contrast, gelatinous zooplankton generally reproduce as soon as the food supply becomes favorable. For example, scyphomedusae (Lucas 1994) and ctenophores (Kremer 1993) reproduce when copepod abundance increases in the spring. Antarctic salps form enormous numbers of chain-forming sexual blastozooids ('salp bloom') at the onset of primary production or under favorable feeding conditions (Foxton 1966).

Although there are 2 previous studies of seasonal variation in the biochemical composition of chaetognaths (Reeve et al. 1970, Båmstedt 1978), causes of the variability are uncertain (see 'Discussion'). The present study reports temporal variation in the biochemical composition and reproductive cycle of the boreal chaetognath Parasagitta elegans from the hyperbenthic zone of Conception Bay, Newfoundland, in relation to food availability over a $14 \mathrm{mo}$ period. The hyperbenthic zone of Conception Bay has several advantages for examining the biochemical variability of $P$. elegans. We have shown that individuals of all reproductive stages are highly concentrated in the hyperbenthic zone, 1 to $2 \mathrm{~m}$ above the bottom, making a study of the entire life cycle possible (Choe \& Deibel 2000). Secondly, temperature and salinity in the hyperbenthic zone are relatively constant year-round (i.e. $-1^{\circ} \mathrm{C}$, and $33 \%$, deYoung \& Sanderson 1995), enabling examination of biological factors in the absence of confounding seasonality in physical conditions. Finally, there is much historical data on biological dynamics in Conception Bay. The spring phytoplankton bloom begins in late March, with peak phytoplankton biomass being reached in April (Redden 1994). Some species of benthic and hyperbenthic invertebrates respond quickly to this pulse of energy by laying down lipid stores (Parrish et al. unpubl. data). However, we do not know whether, or how, gelatinous carnivores such as P. elegans respond to seasonal pulses of energy from lower trophic levels. This is the question addressed in this paper.

\section{MATERIALS AND METHODS}

Sample collection. Parasagitta elegans were collected from April 1997 to June 1998 at a site in Conception Bay, Newfoundland, with a bottom depth of ca. $235 \mathrm{~m}\left(47^{\circ} 32.2^{\prime} \mathrm{N}, 53^{\circ} 07.9^{\prime} \mathrm{W}\right)$. Individuals in the hyperbenthic zone were collected within $1 \mathrm{~m}$ of the bottom with an opening and closing epibenthic sledge equipped with a $500 \mu \mathrm{m}$-mesh net and Tsurumi-SeikiKosakusho (TSK) mechanical flowmeter. The sledge was fitted with a butterfly-valve door which was held closed by a length of surgical tubing when the sledge was suspended in the water column. Upon contact with the bottom, a lever caused the door to open, and a magnetic switch on the door sent an acoustic signal to a hydrophone towed behind the boat to indicate door status. The acoustic transmitter (Vemco) also relayed depth and temperature data to the boat in real time. The sledge was towed on the bottom at 1.0 to 1.5 knots for 17 to $25 \mathrm{~min}$. The samples were collected every 1 to 2 wk from April to June and monthly during other months, but only a few samples were obtained during winter due to bad weather.

Cod-end contents from an initial sledge tow were fixed in $4 \%$ buffered formaldehyde-seawater for later determination of the body size and maturity stage of chaetognaths. Live individuals from a second, replicate tow were examined under a dissecting microscope. Healthy individuals without food and parasites in their guts were removed, rinsed quickly in distilled water and blotted on pre-combusted glass-fiber (GF/C) filters. The individuals were stored at $-80^{\circ} \mathrm{C}$ and later lyophilized for $2 \mathrm{~d}$ for biochemical analyses.

Chemical analyses. Total lipid was determined by a gravimetric procedure after chloroform/methanol extraction (Bligh \& Dyer 1959). Carbon and nitrogen were determined with a Perkin-Elmer CHN analyzer (Model 2400) standardized with acetanilide. The coefficient of variation of carbon measurements from replicate samples of acetanilide was $0.5 \%$. Total protein was estimated by multiplying nitrogen content values by 5.8. This nitrogen-protein conversion factor is based on the nitrogen fraction in protein of bacteria, algae and aquatic animals, and is accurate within 3\% (Gnaiger \& Bitterlich 1984). Carbohydrate was extracted from the lyophilized tissue by boiling in a solution of $5 \%$ trichloroacetic acid containing $50 \mathrm{mg}$ silver sulphate (Barnes \& Heath 1966). The concentration of carbohydrate was determined by the phenol-sulphuric acid colorimetric procedure (Dubois et al. 1956). Ash content was obtained by reweighing dried samples after combustion at $450^{\circ} \mathrm{C}$ in a muffle furnace overnight. The carbohydrate assay required $60 \mathrm{mg}$ of lyophilized tissue, while $60 \mathrm{mg}$ was used for the lipid assay, 3 to $15 \mathrm{mg}$ for ash content and 3 to $6 \mathrm{mg}$ for CHN analysis, requiring pooling 40 to 641 individuals, depending on the body sizes of the individuals available. All assays were carried out in triplicate except the CHN analyses, which were done in duplicate. The levels of the various constituents were expressed in terms of \% dry weight to normalize for seasonal changes in body size and mass.

Body length and gonad maturity. The body length of preserved chaetognaths was measured from the tip of the head to the tip of the tail, excluding fins, to the 
nearest millimeter, and the stage of maturity was determined under a M5 Wild stereo microscope at 25x magnification according to Sameoto (1987): Stage I: ovaries are visible or very small and testes are undeveloped; Stage II: ovaries are visible but eggs are small and uniform, testes are developed and visible, seminal receptacles are developing; Stage III: ovaries are welldeveloped with many eggs larger than others, seminal receptacles are well developed.

Abundance of copepods in water column and hyperbenthic zone. From May 1997 to June 1998, copepods were collected from 2 depth intervals in the water column (50 to 175 and 175 to $225 \mathrm{~m}$ ) with a closing Tucker Trawl fitted with a $500 \mu \mathrm{m}$-mesh net and TSK flowmeter. The copepods in the hyperbenthic zone were collected at the same time as chaetognaths were collected using the benthic sledge. The abundance and stages of copepod species were determined from subsamples with a Motoda zooplankton splitter (Motoda 1959). The minimum number of major copepod species counted within each developmental stage was 30, resulting in maximum $95 \%$ confidence intervals (i.e. analytical error) ranging from 30 to $56 \%$ of the count (Alden et al. 1982).

Statistical analyses. The raw time-series data were arcsine-transformed prior to statistical analyses. In order to depict the general trend in our temporal data, we applied the cumulative sum (CUSUM) technique to the normal standard deviates. This procedure displays changes in the level of the variables as well as the point of onset of such changes (Page 1954, Barnard 1959, Woodward \& Goldsmith 1964, Davis \& Goldsmith 1972). First, each raw time-series was transformed to a series of the normal standard deviate by calculating the relative change of each data point from the grand mean. Next, these transformed time-series were smoothed by the cumulative sum of each normal standard deviate as follows:

$$
\begin{gathered}
S_{1}=\left(y_{1}-k\right) \\
S_{2}=\left(y_{1}-k\right)+\left(y_{2}-k\right)=S_{1}+\left(y_{2}-k\right) \\
S_{3}=S_{2}+\left(y_{3}-k\right), \ldots \text { to } \\
S_{t}=S_{t}-1+\left(y_{t}-k\right)=\sum_{i=1}^{t}\left(y_{i}-k\right)
\end{gathered}
$$

where $S$ is the cumulative sum and $t$ is the time in days at the $i$ th time point, and $k$ is the normal standard deviate, $\left(y_{i}-\mu\right) / \delta$. A positive slope in a time-series of CUSUM reflects an extended period of raw data values above the grand mean and a negative slope reflects extended periods below the grand mean. Finally, simple correlation analysis was applied to the data expressed in CUSUMS using SPSS statistical software (SPSS 9.0.0 1998).

\section{RESULTS}

\section{Seasonal variation in biochemical composition}

Parasagitta elegans was protein-rich, which is typical of gelatinous zooplankton. The grand mean $( \pm \mathrm{SD})$ protein and lipid levels were $64.4 \pm 3.7 \%$ and $13.1 \pm$ $1.5 \%$ of dry weight, respectively, followed by carbohydrate at $0.6 \pm 0.1 \%$. The grand means for carbon and ash levels were $41.3 \pm 0.8 \%$ and $11.8 \pm 2.3 \%$, respectively, and the mean $\mathrm{C} / \mathrm{N}$ ratio was $4.4 \pm 0.2$. Carbon level was least variable (coefficient of variation, $\mathrm{CV}=1.9 \%$ ), while ash level was most variable $(\mathrm{CV}=19 \%)$. The sum of the mean protein, lipid, carbohydrate and ash levels was $89.9 \pm 3.7 \%$ of the dry weight. Adding a residual water fraction of $6 \%$ obtained from fish, zooplankton and algae (Gnaiger \& Bitterlich 1984), leaves only ca. $4 \%$ of the total dry weight unaccounted for. This indicates that our analytical methods were satisfactory, including the indirect approach to estimation of protein content (see 'Materials and methods').

The biochemical composition of Parasagitta elegans showed clear seasonal patterns (Fig. 1A-F). The lipid level was above the mean from April to August 1997, decreased below the mean from October 1997 to May 1998 and increased again in July 1998. The protein level was below the grand mean from April to July 1997, increased above the mean from August 1997 to April 1998 and decreased in May and June 1998. Carbohydrate was mostly above the mean from April to July 1997, decreased below the mean from August 1997 to April 1998 and increased from April to June 1998. Ash level was mostly above the mean from April to October 1997 with a sharp increase in August and October and a decrease from November 1997 to June 1998. Carbon was below the mean from April to October 1997, increased above the mean from November 1997 to May 1998 and decreased in June 1998. The C/N ratio was above the mean from April to July 1997, decreased below the mean from July 1997 to February 1998 and increased from April to June 1998.

When the data are displayed as CUSUMS, clear seasonal variation in the biochemical composition becomes apparent (Fig. 1G-L). The positive slope in the CUSUM of each biochemical constituent indicates the period in which the biochemical level was higher than the grand mean, and the negative slope when the level was lower than the grand mean. The smoothed CUSUM time-series reveal obvious similarities in the seasonal variability of lipid, carbohydrate and the $\mathrm{C} / \mathrm{N}$ ratio, and clear inverse relationships between these three and protein, and between ash and carbon. 

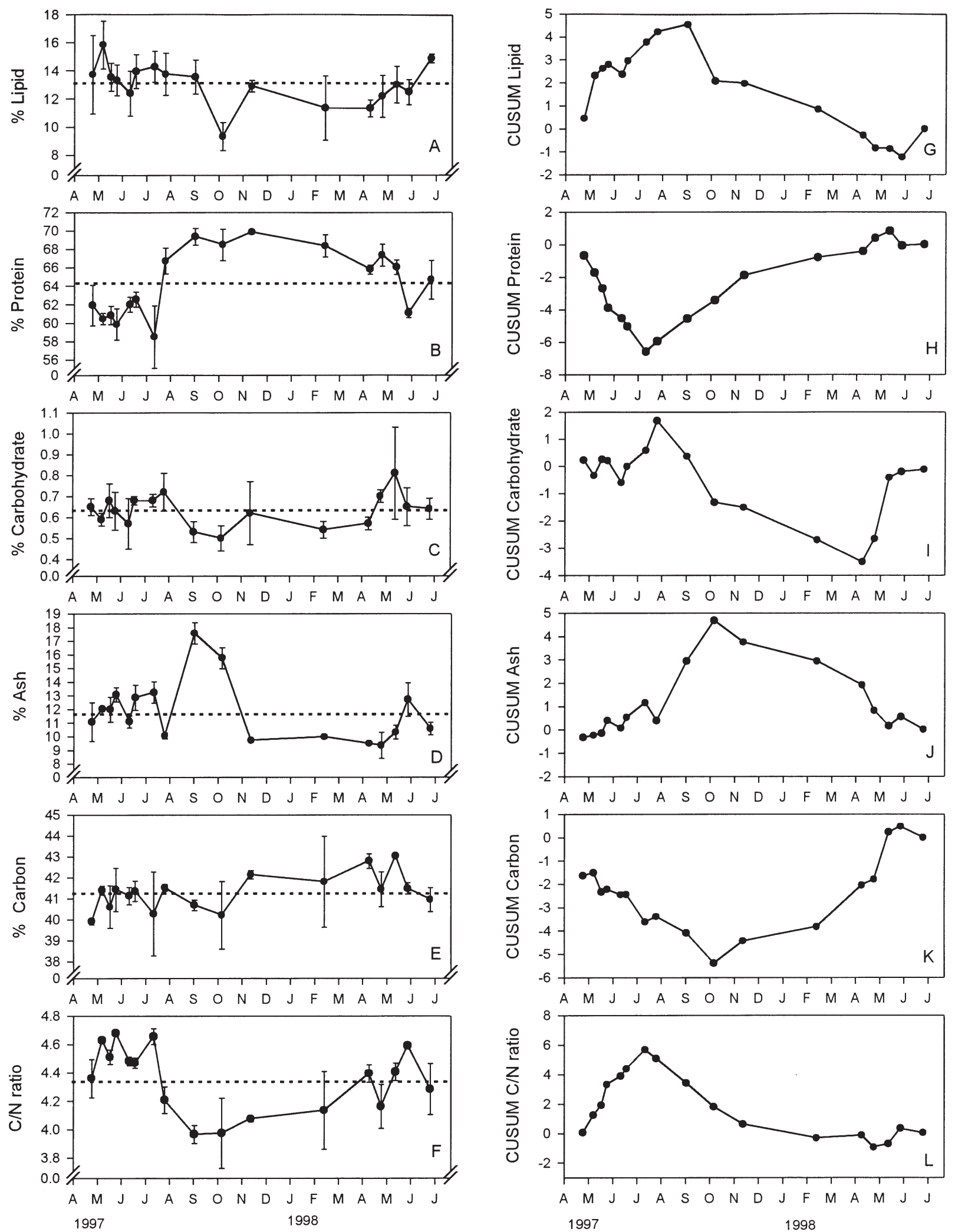

Fig. 1. Parasagitta elegans. Biochemical levels (A-F) and cumulative sums of normal standard deviates of the biochemical levels (G-L) from April 1997 to June 1998. Biochemical levels expressed in percent dry weight. Dashed lines represent means; error bars represent analytical variance among replicate pools of chaetognaths taken from single tow 


\section{Biochemical composition and reproductive cycle}

There was a clear seasonal pattern in the life-history stage composition of hyperbenthic Parasagitta elegans. Large mature Stage III individuals dominated the samples from late May through mid-July 1997 and in late May 1998, making up 55 to $90 \%$ of all individuals (Fig. 2). From June to October 1997, there was a relative increase in the frequency of immature Stage I individuals, which increased from ca. 10 to $80 \%$. These Stage I individuals clearly metamorphosed into Stage II juveniles between November 1997 and April 1998, when Stage II comprised ca. $80 \%$ of the total sample. There was relatively rapid maturation of Stage II into Stage III individuals during April and May 1998. Thus the samples were dominated by Stage III in May and June, Stage I in October and November, and Stage II in February and April.

Correlations between the CUSUMs of the relative proportion of mature Stage III individuals and the biochemical composition show strong relationships between temporal variations in the reproductive cycle and biochemical composition of Parasagitta elegans (Fig. 3). Levels of lipid, carbohydrate and the $\mathrm{C} / \mathrm{N}$ ratio were positively correlated with the percent of Stage III individuals (Fig. 3A, C,F). The level of protein was negatively correlated with the proportion of mature individuals (Fig. 3B). The levels of ash and carbon were not significantly correlated with the relative proportion of mature chaetognaths (Fig. 3D,E). These data suggest that during maturation in the spring and summer, $P$. elegans does not increase its total organic matter (i.e. carbon) as a proportion of dry weight, but only changes its biochemical composition by increasing the proportion of lipid and carbohydrate and decreasing the proportion of protein.

\section{Biochemical levels and abundance of mature copepods}

It should be noted that the abundance of copepods reported in this study is an underestimate, since we used a plankton net with a relatively large mesh size $(500 \mu \mathrm{m})$ to be consistent in the collection of zooplankton from the hyperbenthic zone and the water column. Nevertheless, the abundance of major species of adult copepods varied seasonally (Fig. 4). The abundances of adults of the genera Calanus, Pseudocalanus, and Metridia were high in May and June of 1997 and
1998. There was a sharp increase in the abundance of adult Temora spp. in November 1997; this sudden increase is not likely to be an outlier, since this increase occurred in all 3 depth layers, i.e. in 2 different net tows in the water column as well as in the hyperbenthic sledge tow (data not shown). The total abundance of adult copepods was well above the grand mean in May and June of 1997 and slightly above the mean in April and May of 1998. The number of adult copepods in the spring was higher in 1997 than in 1998, and this interannual variation was largely attributable to Pseudocalanus species.

The temporal variation in the abundance of adult copepods was highly correlated with the biochemical levels of Parasagitta elegans (Fig. 5). The abundance of total adult copepods was positively correlated with lipid and carbohydrate levels and with the $\mathrm{C} / \mathrm{N}$ ratio (Fig. 5A,C,F), but negatively correlated with protein levels (Fig. 5B). No correlations were found with the levels of ash and carbon (Fig. 5D,E).

\section{DISCUSSION}

\section{Seasonal variation in biochemical composition}

Although seasonal variability in the biochemical composition of chaetognaths has been reported previously, causal mechanisms have remained elusive. In Biscayne Bay, Florida, USA, Sagitta hispida had decreased levels of protein and increased levels of lipid

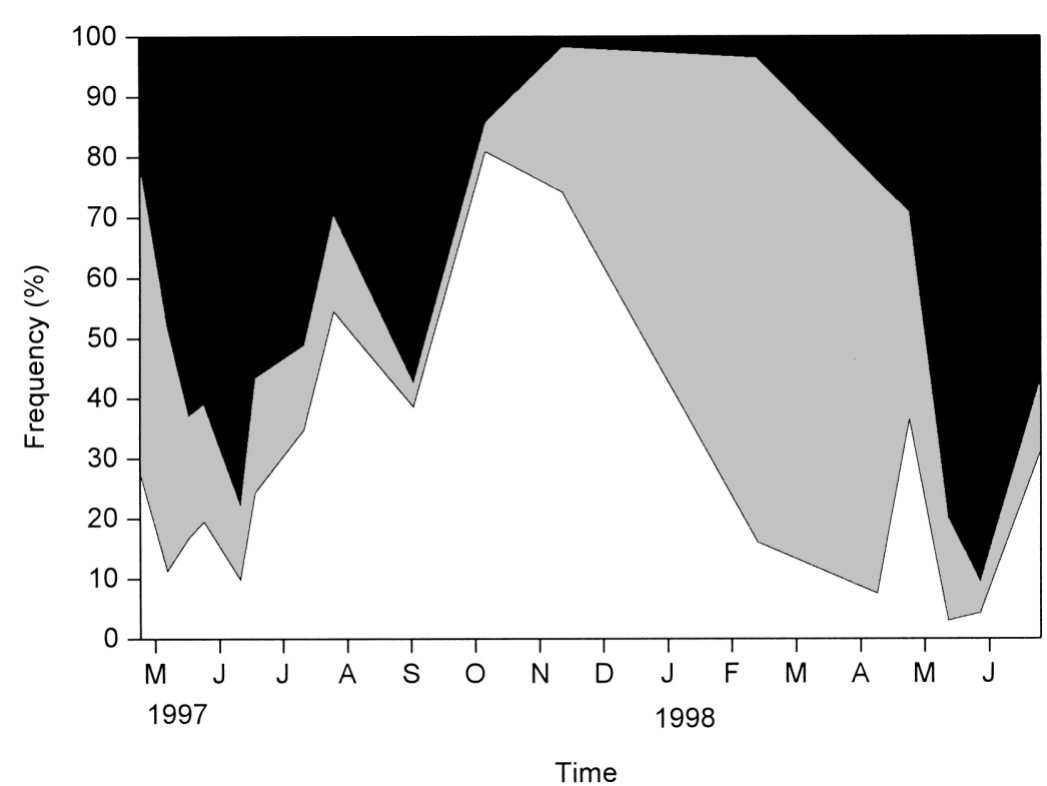

Fig. 2. Parasagitta elegans. Annual reproductive cycle, showing relative frequency distributions of life-history Stages I to III (see 'Materials and methods' for stage definitions). $\square$ : Stage I, $\square$ : Stage II, $\mathbf{\square}$ : Stage III 

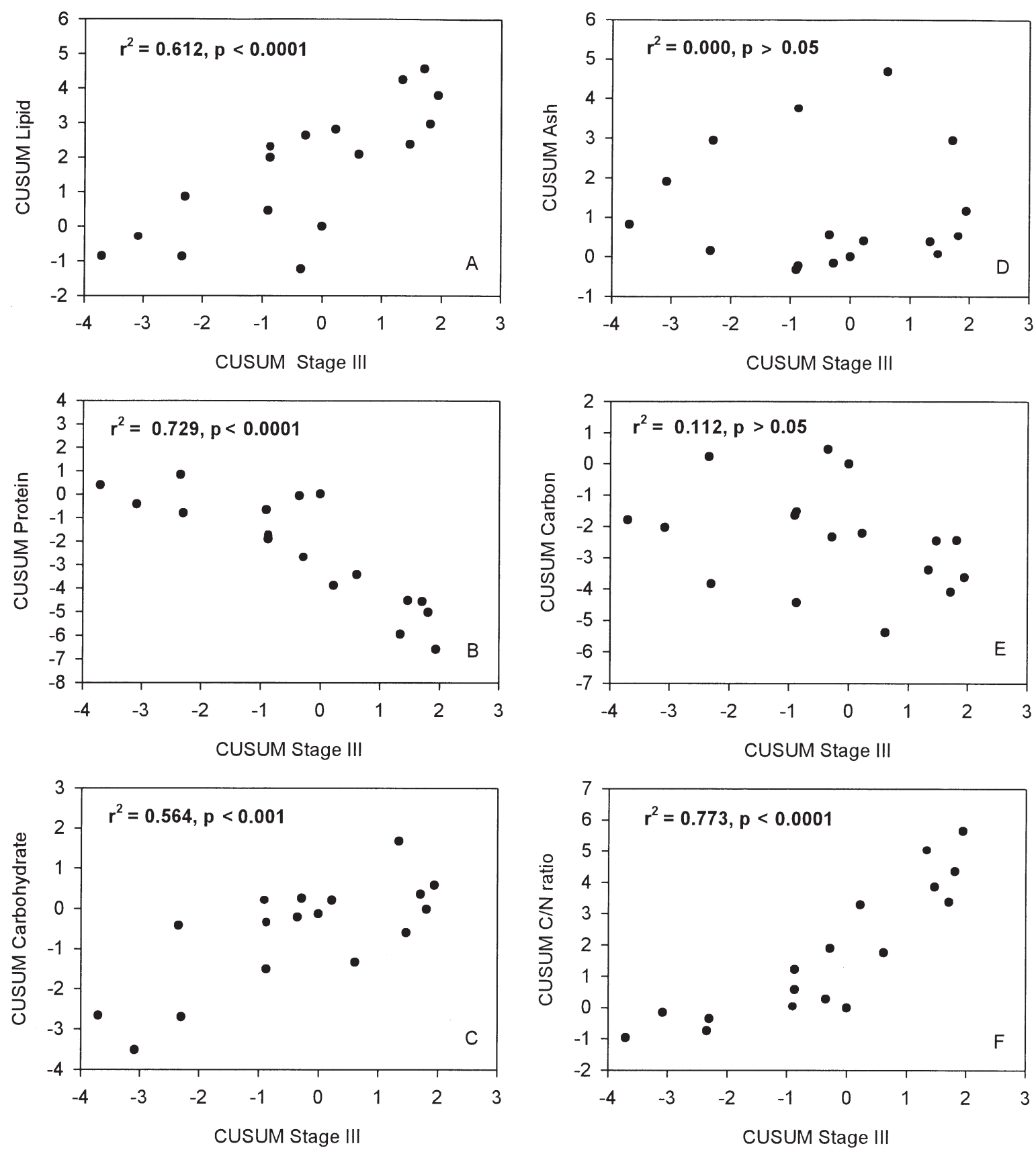

Fig. 3. Parasagitta elegans. Correlations between cumulative sums of normal standard deviates of the relative proportion of mature Stage III individuals in the tows and (A) lipid, (B) protein, (C) carbohydrate, (D) ash, (E) carbon, (F) C/N ratio. $\mathrm{r}^{2}=$ coefficient of determination, $\mathrm{p}=$ significance at $95 \%$ level $(\mathrm{n}=17)$

and ash during spring and fall (Reeve et al. 1970). This seasonal pattern could not be explained by the reproductive cycle of $S$. hispida, which has a lifespan of a few weeks and, as a species, reproduces continuously throughout the year. The copepods that are the major prey of $S$. hispida also reproduce continuously, indicating that food availability is not the cause of seasonal biochemical variation in S. hispida. Furthermore, the biochemical composition of $S$. hispida remained constant even when individuals were starved for $25 \%$ of the generation time. However, the biochemical changes appear to be related to salinity fluctuation (30 to $35 \%$ ), protein decreasing and ash increasing as salinity rises. This salinity effect is also found in other gelatinous zoo- 
plankton such as hydromedusae and scyphomedusae (Larson 1985, Wright \& Purcell 1997, Hirst \& Lucas 1998). When these zooplankton are exposed to higher salinity, they increase their bound water, resulting in an increase in dry weight; they also increase their ash weight to maintain buoyancy by selectively exchanging ions (Robertson 1949, Bidigare \& Biggs 1980). Therefore, the decrease in the protein level of $S$. hispida at higher salinity is probably due to an increase in bound water and, subsequently, dry weight. S. hispida may also control its buoyancy by increasing its ash content when exposed to higher salinity.

In Korsfjorden, Norway, Eukrohnia hamata from below $300 \mathrm{~m}$ had increased levels of protein and ash in the spring and increased levels of lipid in the fall and winter (Båmstedt 1978). However, this pattern was not related to its seasonal reproductive cycle, since the high lipid levels were also present in immature stages and there were no significant correlations between biochemical composition and body size, which was used as an indicator of maturity. Furthermore, the observed variability in biochemical composition could not be explained by physical variability, since temperature and salinity were relatively constant below 300 m in Korsfjorden. Therefore, food availability is considered to be the most likely factor influencing seasonal changes in the biochemical composition of E. hamata (Båmstedt 1978).

In contrast to these previous studies, seasonality in the biochemical composition of Parasagitta elegans from the hyperbenthic zone of Conception Bay is clearly a function of both the reproductive cycle and (perhaps) food quality. Lipid and carbohydrate levels increase as $P$. elegans makes the transition from Stage II to Stage III in the spring and summer. These changes are probably affected by food quality rather than food abundance because they occur when large, mature, energy-rich copepods appear in the spring and summer rather than when the total abundance of copepodites increases in the fall (Davis 1982, Myers et al. 1994).

In Conception Bay, our evidence indicates that energy transfer from primary producers to secondary and tertiary consumers is tightly and temporally coupled. As the spring bloom progresses in April and
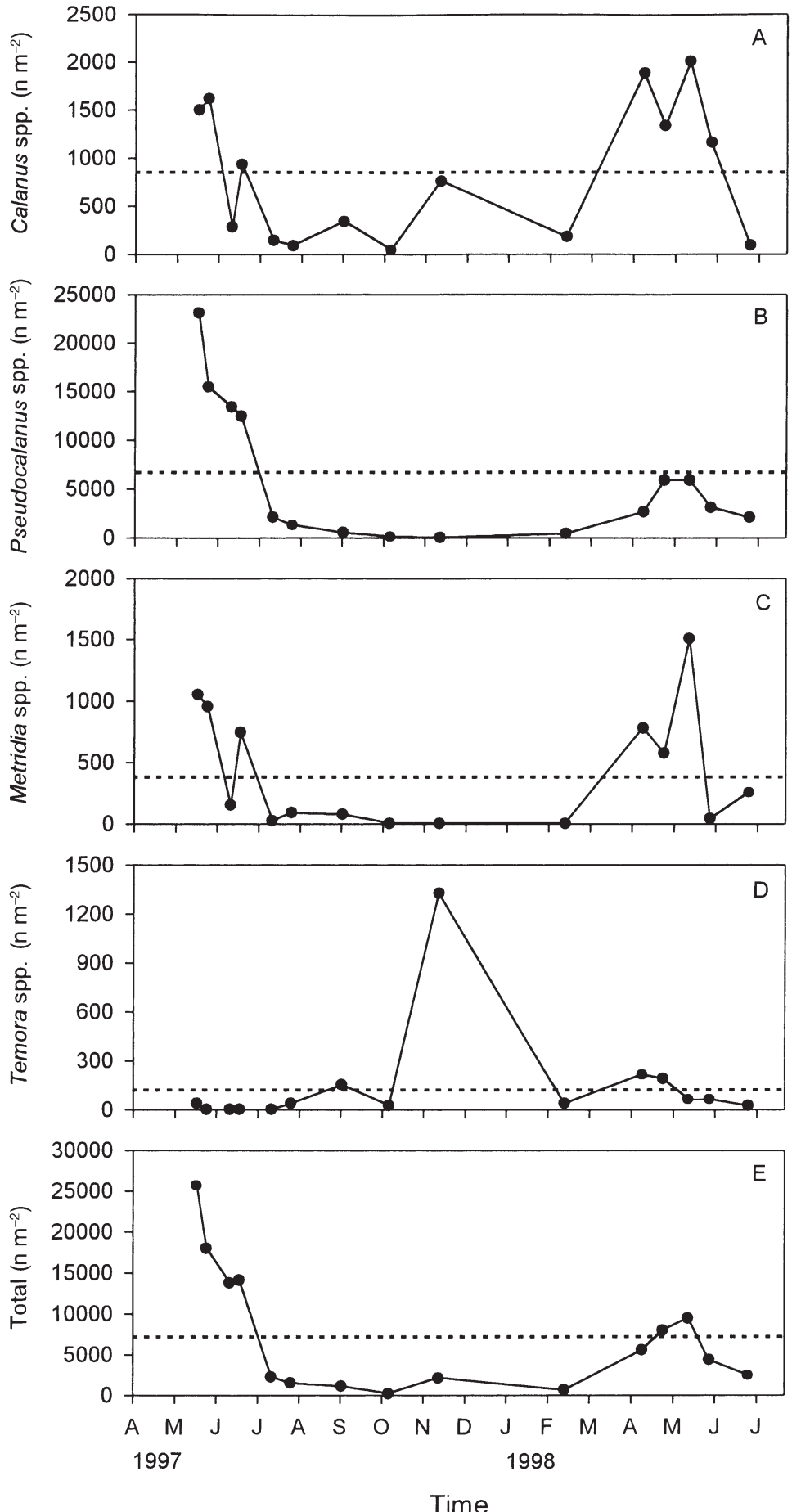

Fig. 4. Abundance of CVI female copepods from May 1997 to June 1998. (A) Calanus spp., (B) Pseudocalanus spp., (C) Metridia spp., (D) Temora spp.

(E) Total CVI female copepods. Dashed lines represent the means

May, the abundance of mature copepods increases (Fig. 6). Although we have limited interannual data for comparison, there appears to be a relationship between the intensity of the spring bloom and the 

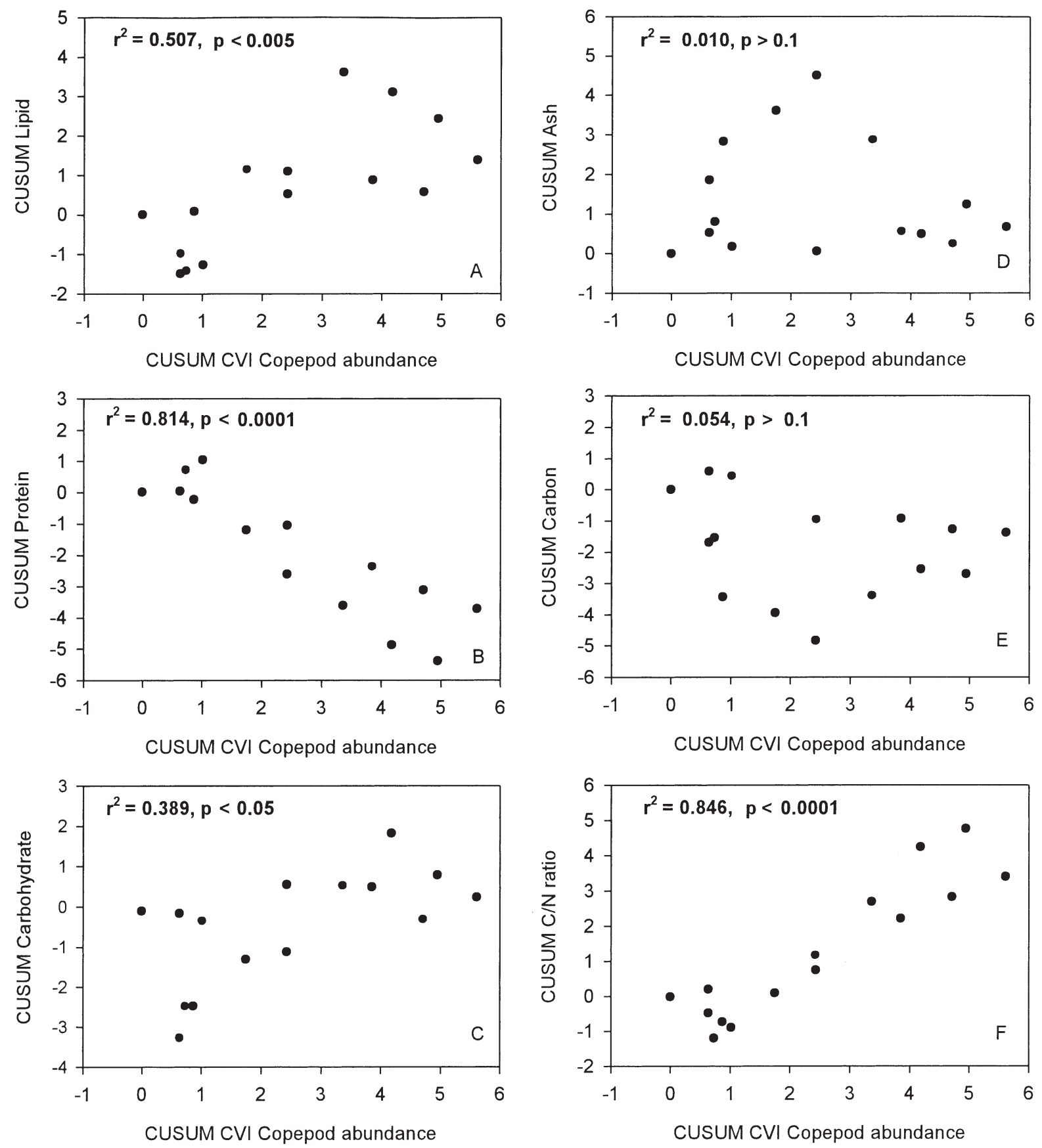

Fig. 5. Correlations between cumulative sums (CUSUM) of normal standard deviates of total female CVI copepods and the following characteristics of the chaetognath Parasagitta elegans: (A) lipid, (B) protein, (C) carbohydrate, (D) ash, (E) carbon, (F) C/N ratio. $\mathrm{r}^{2}=$ coefficient of determination, $\mathrm{p}=$ significance at $95 \%$ level, $\mathrm{n}=15$. Two sets of data are missing, since no copepod abundance data were collected on 23 April and 6 May 1997

abundance of mature copepods. More copepods matured in the spring of 1997, when the intensity of the phytoplankton bloom was higher, than in 1998 when the bloom was less intense (Fig. 6). Responding to the increase in the energy in the lower trophic levels, Parasagitta elegans also increases its levels of lipid and carbohydrate and undergoes sexual maturation in the spring. More specifically, the time lags between the peaks in phytoplankton, mature copepods and mature chaetognaths are ca. 3 wk (Fig. 6). 


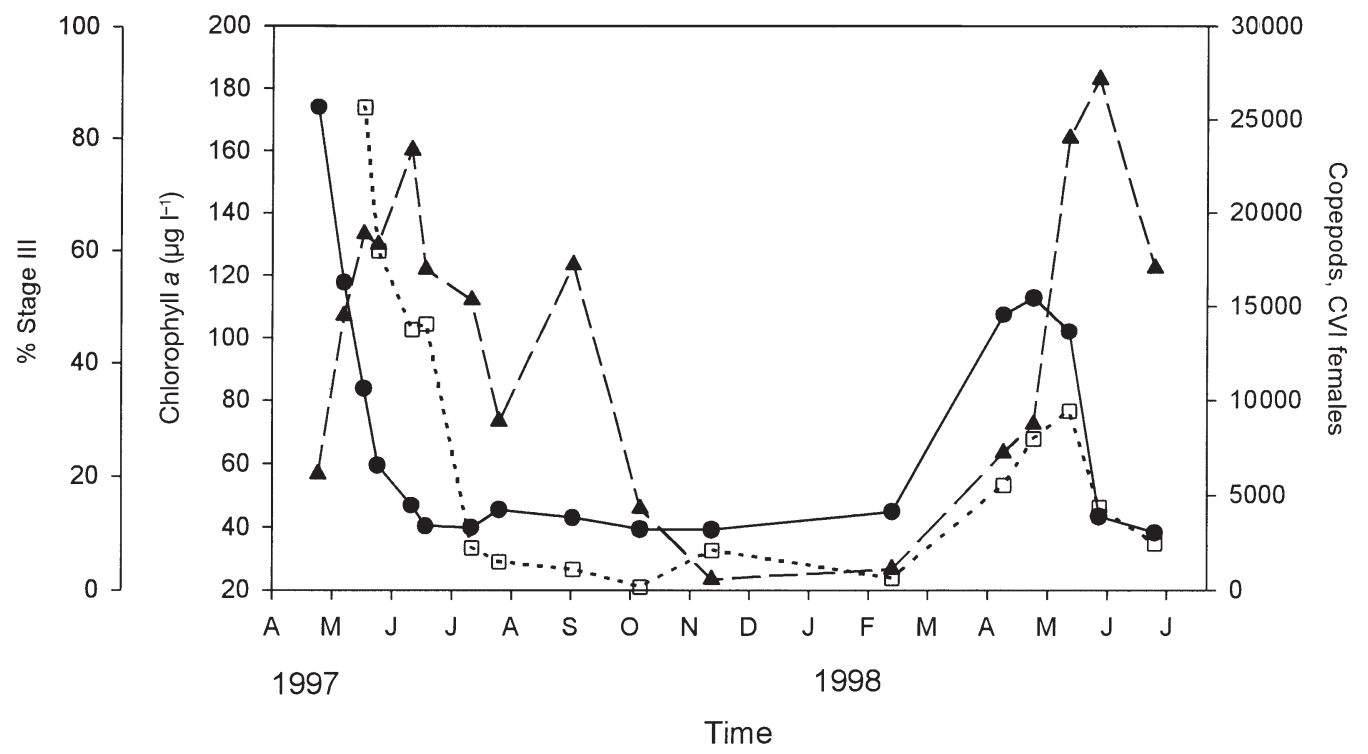

Fig. 6. Concentration of chlorophyll a, abundance of female CVI copepods, and relative proportion of mature Stage III Parasagitta elegans from April 1997 to June 1998. RFU (relative fluorescence unit) readings from in situ fluorometer at $1 \mathrm{~m}$ intervals were converted into chlorophyll a values and integrated from 0 to $200 \mathrm{~m}$. Calibration equation used to convert RFU to chlorophyll $a$ was $y=0.3983 x+0.2815, \mathrm{r}^{2}=0.7302, \mathrm{p}<0.001, \mathrm{n}=244$, standard error $=1.6374, F=654.892$. (•) Chlorophyll $a_{i}(\square)$ female copepods (Stage CVI); (४) \% Stage III P. elegans

\section{Summary}

According to Torres et al. (1994) and Hagen (1999), polar zooplankton generally fall into 1 of 3 categories of energy strategies. Type 1 represents overwintering zooplankton, such as herbivorous copepods, which accumulate large lipid deposits as wax esters and enter diapause. Extreme metabolic reduction and reproduction early in the season is found in the overwintering zooplankton. Type 2 represents zooplankton such as euphausiids, hyperiid amphipods and salps, which do not enter true dormancy during winter, but reduce metabolism and metabolize stored triacylglycerols. They feed opportunistically and reproduce when conditions are favorable. Type 3, such as carnivorous copepods (Euchaeta), decapods, mysids, gammarid amphipods and chaetognaths show no metabolic reduction during the winter and have a prolonged breeding season.

The energy strategy of chaetognaths in the hyperbenthic zone of boreal waters such as Conception Bay differs from the energy strategies of polar zooplankton. Parasagitta elegans does not overwinter, since it grows at a constant rate throughout the year (Choe \& Deibel 2000). Since growth rates and hyperbenthic water temperatures are both constant throughout the year, we conclude that growth is not food-limited. Metabolic reduction probably does not occur in actively growing individuals during winter. Nevertheless, P. elegans appears to require additional energy from the spring phytoplankton bloom to achieve sexual maturity, since it accumulates lipid immediately after the spring bloom and utilizes it for reproduction.

Acknowledgements. We thank Elizabeth Hatfield for assistance with the CHN analyzer and Michael Riehl, the late Nicolai Mumm, and the crew of the RV 'Karl \& Jackie II' for sample collections. We thank Grant Gardner, Erik Thuesen, and Paul Snelgrove for critical reviews of an earlier version of the manuscript. This study was funded by an NSERC Collaborative Project Grant awarded to R.J.T., D.D., C. C. Parrish and J. Abrajano, an NSERC Research Grant to D.D. and a graduate fellowship to N.C.

\section{LITERATURE CITED}

Alden RW, Dahiya RC, Young Jr RJ (1982) A method for the enumeration of zooplankton subsamples. J Exp Mar Biol Ecol 59:185-206

Alonzo F, Mayzaud P, Razouls S (2000) Egg production, population structure and biochemical composition of the subantarctic copepod Paraeuchaeta antarctica in the Kerguelen Archipelago. Mar Ecol Prog Ser 205:207-217

Båmstedt U (1978) Studies on the deep-water pelagic community of Korsfjorden, western Norway: seasonal variation in weight and biochemical composition of Chiridius armatus (Copepoda), Boreomysis arctica (Mysidacea), and Eukrohnia hamata (Chaetognatha) in relation to their biology. Sarsia 63:145-154

Barnard GA (1959) Control charts and stochastic processes. J R Statist Soc 21:239-271 
Barnes H, Heath JR (1966) The extraction of glycogen from marine invertebrate tissues. Helgol Wiss Meeresunters 13: 115-117

Bidigare RT, Biggs DC (1980) The role of sulfate exclusion in buoyancy maintenance by siphonophores and other oceanic gelatinous zooplankton. Comp Biochem Physiol 66:467-471

Bligh EG, Dyer WJ (1959) A rapid method of total lipid extraction and purification. Can J Biochem Physiol 37:911-917

Choe N, Deibel D (2000) Seasonal vertical distribution and population dynamics of the chaetognath Parasagitta elegans in the water column and hyperbenthic zone of Conception Bay, Newfoundland. Mar Biol 137:847-856

Davis CC (1982) A preliminary quantitative study of the zooplankton from Conception Bay, Insular Newfoundland, Canada. Int Rev Ges Hydrobiol 67:713-747

Davis OL, Goldsmith PL (1972) Statistical methods in research and production. Oliver \& Boyd, Edinburgh

deYoung B, Sanderson B (1995) The circulation and hydrography of Conception Bay, Newfoundland. Atmos-Ocean 33:135-162

Dubois M, Gilles KA, Hamilton JK, Rebers PA, Smith F (1956) Colorimetric method for determination of sugars and related substances. Anal Chem 28:350-356

Falk-Petersen S (1981) Ecological investigations on the zooplankton community of Balsfjorden, northern Norway: seasonal changes in body weight and the main biochemical composition of Thysanoessa inermis (Krøyer), T. raschii (M. Sars), and Meganyctiphanes norvegica (M. Sars) in relation to environmental factors. J Exp Mar Biol Ecol 49:103-120

Foxton P (1966) The distribution and life history of Salpa thompsoni Foxton with observations on a related species, Salpa gerlachei Foxton. Discov Rep 34:1-116

Gnaiger E, Bitterlich G (1984) Proximate biochemical composition and caloric content calculated from elemental CHN analysis: a stoichiometric concept. Oecologia 62:289-298

Hagen W (1999) Reproductive strategies and energetic adaptations of polar zooplankton. Inverteb Reprod Dev 36:25-34

Hirst AG, Lucas CH (1998) Salinity influences body weight quantification in the scyphomedusae Aurelia aurita: important implication for body weight determination in gelatinous zooplankton. Mar Ecol Prog Ser 165:259-269

Hopkins CCE, Tande KS, Groenvik S, Sargent JR (1984) Ecological investigations of the zooplankton community of Balsfjorden, northen Norway: an analysis of growth and overwintering tactics in relation to niche and environment in Metridia longa (Lubbock), Calanus finmarchicus (Gunnerus), Thysanoessa inermis (Krøyer) and T. raschi (M. Sars). J Exp Mar Biol Ecol 82:77-99

Kosobokova KN (1999) The reproductive cycle and life history of the Arctic copepod Calanus glacialis in the White Sea. Polar Biol 22:254-263

Kremer P (1993) Ctenophore population dynamics: patterns of abundance of Mnemiopsis in U.S. costal waters. Int Counc Explor Sea Comm Meet 36:1-9

Larson RJ (1985) Trophic ecology of gelatinous predators (Cnidaria and Ctenophora) in Saanich Inlet, Vancouver Island, British Columbia, Canada. PhD thesis, University of Victoria, Victoria

Editorial responsibility: Otto Kinne (Editor), Oldendorf/Luhe, Germany
Lehtonen KK (1996) Ecophysiology of the benthic amphipod Monoporeia affinis in an open-sea area of the northern Baltic Sea: seasonal variations in body composition, with bioenergetic considerations. Mar Ecol Prog Ser 143:87-98

Littlepage JL (1964) Seasonal variation in lipid content of two Antarctic marine Crustacea. In: Carrick R, Holdgate MW, Prévost J (eds) Biologie antarctique. First SCAR Symposium Hermann, Paris, p 463-470

Lucas CH (1994) Biochemical composition of Aurelia aurita in relation to age and sexual maturity. J Exp Mar Biol Ecol 183:179-192

Motoda S (1959) Devices of simple plankton apparatus. Mem Fac Fish Hokkaido Univ 7:73-94

Myers RA, Barrowman NJ, Mertz G, Gamble J, Hunt HG (1994) Analysis of continuous plankton recorder data in the Northwest Atlantic 1959-1992. Can Tech Rep Fish Aquat Sci 1966:1-246

Niehoff B, Klenke U, Hirche HJ, Irigoien X, Head R, Harris R (1999) A high frequency time series at Weathership $M$, Norwegian Sea, during the 1997 spring bloom: the reproductive biology of Calanus finmarchicus. Mar Ecol Prog Ser 176:81-92

Page ES (1954) Continuous inspection schemes. Biometrika 41:100-115

Pasternak A, Arashkevich E, Tande K, Falkenhaug T (2001) Seasonal changes in feeding, gonad development and lipid stores in Calanus finmarchicus and C. hyperboreus from Malangen, northern Norway. Mar Biol 138:1141-1152

Percy JA (1979) Seasonal changes in organic composition and caloric content of an Arctic marine amphipod, Onisimus (=Boeckosimus) affinis H.J. Hansen. J Exp Mar Biol Ecol 40:183-192

Percy JA, Fife FJ (1981) The biochemical composition and energy content of Arctic marine macrozooplankton. Arctic 34:307-313

Redden AM (1994) Grazer-mediated chloropigment degradation and the vertical flux of spring bloom production in Conception Bay, Newfoundland. PhD thesis, Memorial University of Newfoundland, St. John's

Reeve MR, Raymont JEG, Raymont JKB (1970) Seasonal biochemical composition and energy sources of Sagitta hispida. Mar Biol 6:357-364

Robertson JD (1949) Ionic regulation in some marine invertebrates. J Exp Biol 26:182-200

Sameoto DD (1987) Vertical distribution and ecological significance of chaetognaths in the arctic environment of Baffin Bay. Polar Biol 7:317-328

Sargent JR, Lee RF, Nevenzel JC (1978) Marine waxes. In: Kolattukudy P (ed) Chemistry and biochemistry of natural waxes. Elsevier, Amsterdam, p 50-91

Torres JJ, Donnelly J, Hopkins TL, Lancraft TM, Aarset AV, Ainley DG (1994) Proximate composition and overwintering strategies of Antarctic micronektonic Crustacea. Mar Ecol Prog Ser 113:221-232

Woodward RH, Goldsmith PL (1964) Cumulative sum techniques. Monograph No. 3. Oliver \& Boyd, Edinburgh, p 1-9

Wright DA, Purcell JE (1997) Effect of salinity on ion shifts in mesohaline scyphomedusae, Chrysaora quinquecirrha. Biol Bull 192:332-339

Submitted: November 13, 2000; Accepted: October 25, 2002 Proofs received from author(s): March 24, 2003 